\title{
Bioaccumulation of heavy metals in the black soldier fly, Hermetia illucens and effects on its life cycle
}

\author{
S. Diener ${ }^{1 *}$, C. Zurbrügg ${ }^{1}$ and K. Tockner ${ }^{1,2,3}$ \\ ${ }^{1}$ Eawag: Swiss Federal Institute of Aquatic Science and Technology, P.O. Box 611, 8600 Dübendorf, Switzerland; ${ }^{2}$ IGB, \\ Leibniz-Institute for Freshwater Ecology and Inland Fisheries, Mueggelseedamm 310, 12587 Berlin, Germany; ${ }^{3}$ Freie \\ Universität Berlin, Institute of Biology, Takustrasse 3, 14195 Berlin, Germany; stefan.diener@eawag.ch
}

Received: 25 December 2014 / Accepted: 22 May 2015

(c) 2015 Wageningen Academic Publishers

\section{RESEARCH ARTICLE}

\begin{abstract}
In developing countries, effective waste management strategies are constrained by high collection costs and lack of adequate treatment and disposal options. The organic fraction in particular, which accounts for more than 50\% of the waste production, constitutes a great, yet mostly neglected, reuse potential. Concomitantly, the demand for alternative protein sources by the livestock feed industry is sharply increasing. A technology that effectively transforms organic waste into valuable feed is therefore a timely option. Larvae of the non-pest black soldier fly, Hermetia illucens L. (Diptera: Stratiomyidae), may be used to reduce the mass of organic waste significantly. Concurrently, larval feeding converts organic waste into prepupae (last larval stage) which is high in protein. In combination with a viable market, this potential animal feed may cover the waste collection costs and thus promote innovative, small-scale entrepreneurs to establish a profitable business niche. Organic waste, however, often contains persistent pollutants, such as heavy metals, that may accumulate in the larvae and prepupae of black soldier flies and consequently in the food chain. In this study, we fed black soldier fly larvae chicken feed spiked with heavy metals (cadmium, lead and zinc at three concentrations each) to examine the extent of metal accumulation in the different life stages and the effect of heavy metal concentration in the feed on the life cycle determinants of the flies. The cadmium accumulation factor in prepupae (metal concentration in the body divided by metal concentration in the food) ranged between 2.32 and 2.94; however, the lead concentration remained well below its initial concentration in the feed. The bioaccumulation factor of zinc in prepupae decreased with increasing zinc concentration in the feed (from 0.97 to 0.39). None of the three heavy metal elements had significant effects on the life cycle determinants (prepupal weight, development time, sex ratio).
\end{abstract}

Keywords: bioaccumulation, developing countries, food security, organic waste management, protein

\section{Introduction}

Urban poverty is a fundamental challenge in low and middle-income countries associated with rapid urban sprawl (Moore et al., 2003). The urban poor suffer most from inadequate sanitary services and deficient municipal solid waste management leading to increased health risks and impaired household resilience. While informal collection and recycling systems of inorganic material with a market value are currently available, the organic waste fraction often remains uncollected and untreated. Indiscriminately dumped organic waste accumulates along streets, clogs stormwater drains, pollutes water bodies, rots, and attracts disease-transmitting vectors (e.g. flies, rodents), thus posing serious direct or indirect health risks to local residents. Local authorities, community-based organisations, nongovernmental organisations and research institutions have recognised this deficiency and identified the need for simple, environmentally and economically sustainable organic waste treatment solutions in urban areas (Fluitman, 2000; Zurbrügg et al., 2007).

In many low and middle-income countries, the mass of organic waste may be substantially reduced using larvae of the non-pest black soldier fly, Hermetia illucens L. (Diptera: Stratiomyidae) (Diener et al., 2009). H. illucens larvae feed 
voraciously on decaying organic leftovers from markets and restaurants, animal droppings and on human faeces. Myers et al. (2008) and Sheppard et al. (1994) reported a $33-58 \%$ reduction in organic matter from cow manure and $50 \%$ from chicken manure respectively and Diener et al. (2011) reached a dry matter reduction of $70 \%$ in municipal organic waste.

The final larval instar of $H$. illucens is called the prepupa and consists of $32-44 \%$ raw protein and 33-35\% crude fat (Booram et al., 1977; Diener et al., 2009; St-Hilaire et al., 2007). Hence, larval feeding converts organic waste into a highly valuable protein that may be used as a substitute for fishmeal. The increase in aquaculture led to a growing demand for feed for aquatic organisms and therefore to increasing prices (Riddick, 2014). Fishmeal is becoming less available and the production and the sale of insect protein can thus contribute to cover the waste collection costs as well as allow innovative, small-scale entrepreneurs to establish a profitable business niche.

However, organic waste often contains persistent pollutants such as heavy metals that may accumulate in larvae and prepupae and therefore enter the food chain. The heavy metals enter the waste stream in various ways, be it through atmospheric emissions or inappropriate disposal of heavy metal containing refuse. While terrestrial organisms ingest contaminants orally (biomagnification), aquatic organisms also enrich pollutants in their biomass through diffusion (bioconcentration). Bioaccumulation refers to both bioconcentration and biomagnification (Walker, 1990). The bioaccumulation factor (BAF) thus is the concentration of a pollutant in organisms divided by its concentration in the diet.

A stable black soldier fly population generating viable eggs and producing healthy offspring are prerequisites for running a sustainable organic waste treatment facility using black soldier flies. However, heavy metals in organic waste may influence life history traits. For example copperand lead-contaminated host plants negatively affected fecundity and intrinsic rate of natural increase $\left(\mathrm{r}_{\mathrm{m}}\right)$ in the cabbage aphid, Brevicoryne brassicae L. (Görür, 2006). Reduced bodyweight in the offspring of the carabid beetle, Pterostichus oblongopunctatus, inhabiting a metal-polluted environment has been observed by Lagisz and Laskowski (2008) and Moroń et al. (2014) found a clear relation between increasing metal concentrations in the soil layer and the increased negative impact on life cycle determinants (e.g. population growth rate, number of brood cells, survival rate) for wild bees, Osmia rufa.

In this study, the larvae of the black soldier fly, H. illucens, were fed with chicken feed contaminated by different levels of cadmium, lead and zinc to investigate the following research questions:
- To what extent do cadmium, lead and zinc - fed at different concentrations - accumulate in the prepupae of the black soldier fly?

- Does heavy metal in the food influence the life cycle determinants of the flies? (i.e. development time, body weight, sex ratio)?

\section{Materials and methods}

\section{Animals}

Black soldier flies, H. illucens L. (Diptera: Stratiomyidae), were obtained from a laboratory colony grown in an indoor cage $(1.5 \mathrm{~m} \times 1.5 \mathrm{~m} \times 2.0 \mathrm{~m})$ at constant temperature $\left(26.5 \pm 0.05{ }^{\circ} \mathrm{C}, 60.8 \pm 0.8 \% \mathrm{RH}\right)$. The room was fitted with two windows as direct sunlight is crucial for successful mating (Tomberlin and Sheppard, 2002).

The newly hatched larvae used for the experiments were reared on chicken feed (UFA 625, digestible energy: $11.7 \mathrm{MJ} / \mathrm{kg}, 60 \%$ moisture). A detailed description of the rearing and hatching facility is given in Diener et al. (2009).

The experiments conducted in Switzerland did not violate Swiss law (e.g. Animal Protection Law, Animal Husbandry Act) or any of the provisions or regulations stipulated in these laws. The experiments also met the International Guiding Principles for Biomedical Research Involving Animals as issued by the Council for the International Organizations of Medical Sciences (CIOMS, 1985).

\section{Experimental setup}

Larvae were fed with chicken feed pellets moistened (final moisture level: 60\%) with either pure deionised water (control) or a solution of deionised water containing heavy metal ions (three concentration levels for each metal). The $2 \% \mathrm{HNO}_{3}$ solutions used for feedstock preparation contained cadmium (1000 mg/kg), lead (1000 mg/kg) or zinc $(10,000 \mathrm{mg} / \mathrm{kg})$. The nominal concentrations in the food were: $0.0 \mu \mathrm{g} / \mathrm{g}$ (control), 2.0, 10.0, and $50.0 \mu \mathrm{g} / \mathrm{g} \mathrm{Cd}$; $0.0 \mu \mathrm{g} / \mathrm{g}$ (control), 5.0, 25.0, and $125.0 \mu \mathrm{g} / \mathrm{g} \mathrm{Pb} ; 0.0 \mu \mathrm{g} / \mathrm{g}$ (control), 100, 500, and 2,000 $\mu \mathrm{g} / \mathrm{g} \mathrm{Zn}$. Low concentrations corresponded to the metal concentrations typical for market vegetables in India or Bangladesh (Alam et al., 2003; Marshall et al., 2003; Sharma et al., 2007). Middle concentrations for cadmium and lead corresponded to concentrations typical for organic waste in Bangladesh or Sweden (Eklind et al., 1997; Rytz, 2001) (Table 1).

Metal concentrations in the control groups were derived from the chicken feed itself. Unfortunately, the experiment series with the low concentrations of zinc were contaminated and the results had to be discarded. However, as the chicken feed itself had similar concentrations of zinc $(145.3 \mathrm{mg} / \mathrm{kg}$, standard error $(\mathrm{SE})=10.1)$ as what was used 
Table 1. Heavy metal concentration in municipal solid waste and vegetables (based on dry weight) compared to the legal maximum threshold level allowed in animal feed, human food and compost. ${ }^{1}$

\begin{tabular}{|c|c|c|c|c|}
\hline & Cadmium (mg/kg) & Lead (mg/kg) & Zinc (mg/kg) & Reference \\
\hline \multicolumn{5}{|l|}{ Heavy metal concentration in municipal solid waste } \\
\hline Sweden & $0.16-0.6$ & $2.4-26$ & $49-165$ & Eklind et al., 1997 \\
\hline Dhaka, Bangladesh & 5.0 & $\mathrm{n} / \mathrm{a}$ & 226 & Rytz, 2001 \\
\hline \multicolumn{5}{|l|}{ Heavy metal concentration in vegetables } \\
\hline Garden vegetables, rural village, Bangladesh & $0.05-0.4$ & $0.2-1.7$ & $11-54$ & Alam et al., 2003 \\
\hline Market vegetables, Delhi, India & $1.0-5.5$ & $0.3-2.2$ & $41-150$ & Marshall, 2003 \\
\hline Field vegetables, Varanasi, India & $0.5-4.3$ & $3-16$ & $3-41$ & Sharma et al., 2007 \\
\hline \multicolumn{5}{|l|}{ Heavy metal limits in animal feed } \\
\hline European Union & 2 & 10 & $\mathrm{n} / \mathrm{a}$ & EC, 2002 \\
\hline \multicolumn{5}{|l|}{ Heavy metal limits in human food } \\
\hline European Union & $0.05-1.0$ & $0.02-1.0$ & $\mathrm{n} / \mathrm{a}$ & EC, 2001 \\
\hline India & $0.1-1.5$ & $0.2-10$ & $5-100$ & Government of India, 1954 \\
\hline \multicolumn{5}{|c|}{ Heavy metal limits in compost from household waste } \\
\hline European Union & 0.7 & 45 & 200 & EC, 1991 \\
\hline Proposed standard in LMIC & 3 & 150 & 300 & Hoornweg et al., 1999 \\
\hline
\end{tabular}

in the experiment with low concentrations $(177.4 \mathrm{mg} / \mathrm{kg}$, $\mathrm{SE}=3.8$ ) we were able to utilise the control series (only chicken feed and its respective zinc concentration) as indication of results for the low zinc concentration series. Thus the control series could be considered as the low zinc concentration series and was compared to the medium and high zinc series.

Each replicate (three replicates per treatment) contained 2007 -day old larvae placed in plastic containers $(14.0 \times 7.5$ $\times 7.0 \mathrm{~cm})$ and covered with nylon tulle held in place by the lid of the box. The lids with nine holes $(\varnothing 15 \mathrm{~mm}$ ) allowed air circulation. The food and larvae were covered with a re-sealable polyethylene bag containing a piece of black cardboard to shield larvae from light. The pre-prepared meal portions were packed into separate polyethylene bags and kept frozen until use. The quantity of the diet was calculated based on $100 \mathrm{mg}$ food (wet weight) per larva and day. The larvae were fed three times a week. Feeding stopped when $50 \%$ of the larvae in the box metamorphosed into prepupae to avoid overfeeding the remaining larvae.

\section{Sampling and analysis}

The samples (larvae, larval exuviae, prepupae, pupal exuviae, and adults) were washed with deionised water, weighed, lyophilised to measure dry weight, and ground in an agate mortar for heavy metal analysis. The food samples and the remains at the end of the experiments, the so-called residue, were treated the same way except for the washing. Larvae and prepupae were killed by freezing $\left(-10^{\circ} \mathrm{C}\right)$, while adults were killed with ethyl acetate. To prepare the samples for the analyses, $\sim 50 \mathrm{mg}$ of the ground material was digested in polytetrafluoroethylene beakers (HPR-300/10; MLS GmbH, Leutkirch im Allgäu, Germany). The material was moistened with deionised water. Approximately $4 \mathrm{ml} \mathrm{HNO}_{3}$ and $1 \mathrm{ml} \mathrm{H}_{2} \mathrm{O}_{2}$ were added before the sample was heated in a laboratory microwave digester (MLS 1200 MEGA; MLS $\mathrm{GmbH})$. The clear solution was diluted with deionised water $(10 \times$ for $\mathrm{Cd}$ and $100 \times$ for $\mathrm{Pb}$ and $\mathrm{Zn}$ ) and analysed with the high resolution inductively coupled plasma-mass spectrometer (HR-ICP-MS, Element II; Thermo Fisher Scientific, Waltham, MA, USA). The standard solutions were made using Merck ICP multi-element standard solution IV (Merck Millipore, Darmstadt, Germany): 10, $100,1000,5,000$ and 10,000 ng/l. The natural river water standard SLRS-4 and the TM-28.3 trace elements fortified calibration standard (National Research Council Canada, Ottawa, Canada) were used as a control. The detection limit for these elements was $10 \mathrm{ng} / \mathrm{l}$.

BAF was calculated according to Walker (1990) as:

$\mathrm{BAF}=\frac{\text { concentration in organism }\left(\mathrm{C}_{\mathrm{i}}\right)}{\text { concentration in food and/or water ingested }\left(\mathrm{C}_{\mathrm{o}}\right)}$

In the present case, $\mathrm{C}_{\mathrm{o}}$ consisted solely of the heavy metal concentration in the food. 


\section{Statistical analyses}

Statistical analyses were performed using SPSS Statistics 17.0 software (SPSS Inc., Chicago, IL, USA). For some data, a violation of the Levene homogeneity of variances was calculated. However, as the groups are equal in size, ANOVA is very robust to this violation.

\section{Results}

\section{Heavy metal accumulation}

In all development stages (larvae, prepupae, and adults), the metal concentration generally increased significantly with increasing metal concentration in the food (Table 2-5). However, BAF, i.e. the ratio of the amount of metal in the body compared to that in the food varied among the different metal elements and development stages (Table 6). In prepupae, the BAF ranged from 2.32 to 2.94 for cadmium, independent of the concentration in the food, while the BAF remained $<1(0.25-0.74)$ for lead. In adults, the BAF was very low for both cadmium and lead concentrations (BAF=0.12-0.21). For zinc, the BAF decreased with increasing concentration in the food (prepupae: from 0.97 to 0.39 ; adults: from 0.98 to 0.19 ). The EU threshold value for cadmium $(2 \mathrm{mg} / \mathrm{kg})$ in animal feed was exceeded in prepupae even at low cadmium concentration $(7.9 \mathrm{mg} / \mathrm{kg}$, $\mathrm{SE}=0.6)$. Only prepupae from the low lead concentration group $(1.5 \mathrm{mg} / \mathrm{kg}, \mathrm{SE}=0.7)$ met the EU concentration limit for lead (10 mg/kg) in animal feed (EC, 2002).

Table 2. Cadmium concentration in soldier flies, Hermetia illucens, at different life stages based on dry weight, in digested material (residue) and in food source. Larvae fed with chicken feed (100 mg/larva/day, 60\% moisture) spiked with cadmium (three different concentrations). ${ }^{1,2}$

\begin{tabular}{|c|c|c|c|c|c|c|c|c|}
\hline & \multicolumn{2}{|l|}{ Control } & \multicolumn{2}{|l|}{ Low cadmium } & \multicolumn{2}{|c|}{ Medium cadmium } & \multicolumn{2}{|l|}{ High cadmium } \\
\hline & Mean (mg/kg) & SE & Mean (mg/kg) & SE & Mean (mg/kg) & SE & Mean (mg/kg) & SE \\
\hline Food & $0.2 \mathrm{a}$ & 0.02 & $2.7 \mathrm{~b}$ & 0.2 & $13.3 b$ & 0.7 & $61.5 b$ & 2.3 \\
\hline Residue & $0.2 \mathrm{a}$ & 0.01 & $2.9 \mathrm{~b}$ & 0.1 & $16.0 \mathrm{bc}$ & 0.4 & $89.8 \mathrm{C}$ & 2.1 \\
\hline Larvae & $0.2 \mathrm{a}$ & 0.02 & $7.0 \mathrm{~d}$ & 0.3 & $32.5 d$ & 0.6 & $170.5 d$ & 8.5 \\
\hline Prepupae & n.d. & - & $7.9 \mathrm{~d}$ & 0.6 & $36.2 d$ & 1.9 & $142.9 \mathrm{e}$ & 8.3 \\
\hline Adults & n.d. & - & $0.6 \mathrm{a}$ & 0.04 & $1.9 \mathrm{a}$ & 0.2 & $7.8 \mathrm{a}$ & 0.4 \\
\hline Larval exuviae & $0.1 \mathrm{a}$ & 0.03 & $2.2 a b$ & 0.3 & $18.8 \mathrm{bc}$ & 4.1 & $54.2 b$ & 3.7 \\
\hline Pupal exuviae & $0.5 \mathrm{~b}$ & 0.1 & $5.2 \mathrm{c}$ & 0.7 & $22.9 \mathrm{c}$ & 2.6 & $94.1 \mathrm{C}$ & 12.1 \\
\hline
\end{tabular}

${ }^{1}$ Mean values followed by the same small letter in the same column do not vary significantly $(P>0.05)$.

${ }^{2} \mathrm{SE}=$ standard error; n.d. $=$ not detected.

Table 3. Lead concentration in soldier flies, Hermetia illucens, at different life stages based on dry weight, in the digested material (residue) and in food source. Larvae fed with chicken feed (100 mg/larva/day, 60\% moisture) spiked with lead at three different concentrations. ${ }^{1,2}$

\begin{tabular}{|c|c|c|c|c|c|c|c|c|}
\hline & \multicolumn{2}{|l|}{ Control } & \multicolumn{2}{|l|}{ Low lead } & \multicolumn{2}{|l|}{ Medium lead } & \multicolumn{2}{|l|}{ High lead } \\
\hline & Mean (mg/kg) & SE & Mean (mg/kg) & SE & Mean (mg/kg) & SE & Mean (mg/kg) & SE \\
\hline Food & $1.1 \mathrm{ab}$ & 0.4 & $5.9 \mathrm{bc}$ & 0.3 & $34.3 \mathrm{c}$ & 1.8 & $142.9 b$ & 2.9 \\
\hline Residue & $0.1 \mathrm{a}$ & 0.01 & $7.8 \mathrm{~cd}$ & 0.6 & $53.2 d$ & 3.3 & 267.9 c & 12.8 \\
\hline Larvae & n.d. & - & $3.8 \mathrm{ab}$ & 0.4 & $22.8 b$ & 1.6 & $141.7 b$ & 17.2 \\
\hline Prepupae & n.d. & - & $1.5 \mathrm{a}$ & 0.7 & $25.3 \mathrm{bc}$ & 1.9 & $40.1 \mathrm{ab}$ & 3.7 \\
\hline Adults & n.d. & - & n.d. & - & $5.9 a$ & 0.57 & $17.3 \mathrm{a}$ & 1.36 \\
\hline Larval exuviae & $5.9 \mathrm{c}$ & 1.3 & $11.3 \mathrm{e}$ & 0.01 & $87.7 \mathrm{e}$ & 4.8 & $312.9 c$ & 74.1 \\
\hline Pupal exuviae & $3.7 \mathrm{bc}$ & 0.1 & $9.3 \mathrm{de}$ & 1.0 & $24.2 b c$ & 2.1 & $66.7 \mathrm{ab}$ & 3.6 \\
\hline
\end{tabular}


Table 4. Zinc concentration in soldier flies, Hermetia illucens, at different life stages based on dry weight, in the digested material (residue) and in food source. Larvae fed with chicken feed (100 mg/larva/day, 60\% moisture) spiked with zinc at three different concentrations. Samples from the series 'Low zinc' were contaminated during the experiment and could not be used for interpretation. ${ }^{1,2}$

\begin{tabular}{|c|c|c|c|c|c|c|c|c|}
\hline & \multicolumn{2}{|l|}{ Control } & \multicolumn{2}{|l|}{ Low zinc } & \multicolumn{2}{|l|}{ Medium zinc } & \multicolumn{2}{|l|}{ High zinc } \\
\hline & Mean $(\mathrm{mg} / \mathrm{kg})$ & SE & Mean $(\mathrm{mg} / \mathrm{kg})$ & SE & Mean (mg/kg) & SE & Mean $(\mathrm{mg} / \mathrm{kg})$ & SE \\
\hline Food & $145.3 b$ & 10.1 & 177.4 & 3.8 & $616 b$ & 37.8 & $2,044 \mathrm{c}$ & 16.2 \\
\hline Residue & $192.3 b$ & 13.1 & $\mathrm{n} / \mathrm{a}$ & - & $1,196 \mathrm{c}$ & 66.7 & $3,313 d$ & 240.9 \\
\hline Larvae & $165.8 b$ & 19.9 & $\mathrm{n} / \mathrm{a}$ & - & $596 \mathrm{~b}$ & 88.0 & $866 b$ & 141.9 \\
\hline Prepupae & $138.9 b$ & 24.3 & $\mathrm{n} / \mathrm{a}$ & - & $513 a b$ & 44.5 & $801 \mathrm{ab}$ & 32.1 \\
\hline Adults & $141.4 b$ & 9.2 & $\mathrm{n} / \mathrm{a}$ & - & $272 a b$ & 22.8 & $389 a b$ & 37.6 \\
\hline Larval exuviae & $275.5 c$ & 13.5 & $\mathrm{n} / \mathrm{a}$ & - & $1,514 \mathrm{c}$ & 240.2 & $1,883 c$ & 104.8 \\
\hline Pupal exuviae & $35.1 \mathrm{a}$ & 4.1 & $\mathrm{n} / \mathrm{a}$ & - & $145 a$ & 39.2 & 334 a & 56.5 \\
\hline
\end{tabular}

Table 5. Kendall's tau rank correlation ( $r$ ) between the heavy metal concentration in food and the concentration values in larvae, prepupae, larval exuviae, and adults of the black soldier fly, Hermetia illucens.

\begin{tabular}{|c|c|c|c|c|c|c|c|c|c|c|c|c|}
\hline & \multicolumn{3}{|l|}{ Larvae } & \multicolumn{3}{|c|}{ Prepupae } & \multicolumn{3}{|c|}{ Larval exuviae } & \multicolumn{3}{|l|}{ Adults } \\
\hline & $r$ & $\mathbf{P}$ & $\mathbf{N}$ & $r$ & $\mathbf{P}$ & $\mathbf{N}$ & $r$ & $\mathbf{P}$ & $\mathbf{N}$ & $r$ & $\mathbf{P}$ & $\mathbf{N}$ \\
\hline Cadmium & $0.778^{*}$ & 0.004 & 12 & $0.833^{*}$ & 0.002 & 9 & $0.722^{*}$ & 0.007 & 9 & $0.741^{*}$ & 0.000 & 18 \\
\hline Lead & $0.778^{*}$ & 0.004 & 9 & $0.833^{*}$ & 0.002 & 9 & $0.778^{*}$ & 0.004 & 9 & $0.671^{*}$ & 0.001 & 17 \\
\hline Zinc & $0.667^{*}$ & 0.012 & 9 & $0.611^{*}$ & 0.022 & 9 & $0.833^{*}$ & 0.002 & 9 & $0.647^{*}$ & 0.000 & 18 \\
\hline
\end{tabular}

\section{Effects of heavy metals on life cycle determinants}

Prepupae treated with cadmium were significantly heavier than the control group. No significant effects were found in prepupae treated with lead and zinc (Table 7). Development time from hatching of the larva to the prepupal stage generally increased with heavy metal concentration although the increase was statistically insignificant (Table 8). Average development time until pupation amounted to 15.2 days $(\mathrm{SE}=0.1)$ and did not differ significantly between treatments or sexes. Heavy metals had no influence on the sex ratio of adults (average males/females ratio: 0.98, $\mathrm{SE}=0.02)$.

\section{Discussion}

The black soldier fly, $H$. illucens, fed with cadmium, lead and zinc, exhibits different accumulation patterns. Larvae and prepupae accumulated cadmium, yet the incorporation of lead and zinc was suppressed as concentrations found in the body were lower than in the food. These findings are consistent with literature data (Figure 1). In the literature reports, the BAF of cadmium uptake by detritivorous insects averages 2.86 ( $\mathrm{SE}=0.30$, range 0.46-6.09) (Gintenreiter et al., 1993; Kazimirova and Ortel, 2000; Kramarz, 1999; Lindqvist, 1992; Maryanski et al., 2002; Ortel, 1995). Cellular cadmium uptake probably occurs through $\mathrm{Ca}^{2+}$ channels. Due to their very similar ionic radii, $\mathrm{Cd}^{2+}$ ions can easily enter the cell via $\mathrm{Ca}^{2+}$ channels, independent of endocytosis or an ATP requiring ion pump (Braeckman et al., 1999). Moreover, Braeckman et al. (1999) found a protein of the HSP70-family induced by elevated cadmium concentrations in the environment of Aedes albopictus (Diptera: Culicidae) cells. Production of this protein, which protects other proteins from denaturation, may also explain the low effect of contaminated food on life-cycle parameters such as development time or fluctuating asymmetry despite the observed bioaccumulation of cadmium (cf. present study). 


\section{S. Diener et al.}

Table 6. Bioaccumulation factor (BAF) for larvae, prepupae and adults of the black soldier fly, Hermetia illucens, fed heavy metal contaminated food at three different concentrations (low, medium and high; Table 2, Table 3 and Table 4). BAF for "low concentration, zinc' was calculated using data from the control group (see explanation in text). Because the concentrations of cadmium and lead in the control group were so low, the analytical error had the effect of providing inaccurate BAFs, and are therefore not shown here. ${ }^{1}$

\begin{tabular}{|c|c|c|c|c|c|c|}
\hline & \multicolumn{2}{|l|}{ Low } & \multicolumn{2}{|c|}{ Medium } & \multicolumn{2}{|l|}{ High } \\
\hline & BAF & SE & BAF & SE & BAF & SE \\
\hline \multicolumn{7}{|l|}{ Cadmium } \\
\hline Larvae & 2.65 & 0.10 & 2.46 & 0.11 & 2.79 & 0.24 \\
\hline Larval exuviae & 0.86 & 0.19 & 1.41 & 0.31 & 0.88 & 0.06 \\
\hline Prepupae & 2.94 & 0.09 & 2.75 & 0.25 & 2.32 & 0.09 \\
\hline Adults & 0.21 & 0.01 & 0.15 & 0.01 & 0.13 & 0.01 \\
\hline \multicolumn{7}{|l|}{ Lead } \\
\hline Larvae & 0.66 & 0.09 & 0.67 & 0.07 & 0.99 & 0.10 \\
\hline Larval exuviae & 1.9 & 0.11 & 2.56 & 0.01 & 2.21 & 0.56 \\
\hline Prepupae & 0.25 & 0.12 & 0.74 & 0.03 & 0.28 & 0.03 \\
\hline Adults & $\mathrm{n} / \mathrm{a}$ & - & 0.17 & 0.01 & 0.12 & 0.01 \\
\hline \multicolumn{7}{|l|}{ Zinc } \\
\hline Larvae & 1.14 & 0.09 & 0.97 & 0.14 & 0.42 & 0.07 \\
\hline Larval exuviae & 1.92 & 0.19 & 2.45 & 0.32 & 0.92 & 0.04 \\
\hline Prepupae & 0.97 & 0.20 & 0.84 & 0.09 & 0.39 & 0.01 \\
\hline Adults & 0.98 & 0.08 & 0.45 & 0.04 & 0.19 & 0.02 \\
\hline
\end{tabular}

Table 7. Prepupal dry weight of Hermetia illucens fed with chicken feed (100 mg/larva/day, $60 \%$ moisture) spiked with three different heavy metals at different concentrations (low, medium and high). ${ }^{1,2}$

\begin{tabular}{|c|c|c|c|c|c|c|c|c|}
\hline & \multicolumn{2}{|l|}{ Control } & \multicolumn{2}{|l|}{ Low } & \multicolumn{2}{|l|}{ Medium } & \multicolumn{2}{|l|}{ High } \\
\hline & Mean (mg) & SE & Mean (mg) & SE & Mean (mg) & SE & Mean (mg) & SE \\
\hline Cadmium & $55.9 a$ & 2.3 & $96.2 \mathrm{c}$ & 10.0 & $75.3 b$ & 2.0 & $83.6 \mathrm{bc}$ & 3.3 \\
\hline Lead & $55.9 \mathrm{ab}$ & 2.3 & $61.5 b$ & 6.8 & 51.3a & 2.1 & $59.1 \mathrm{ab}$ & 0.6 \\
\hline Zinc & $55.9 a$ & 2.3 & $\mathrm{n} / \mathrm{a}$ & - & $64.8 \mathrm{a}$ & 5.7 & $59.2 a$ & 4.8 \\
\hline
\end{tabular}

${ }^{1}$ Mean values followed by the same small letter in the same row do not vary significantly $(P>0.05)$.

${ }^{2} \mathrm{SE}=$ standard error; $\mathrm{n} / \mathrm{a}=$ not applicable.

Table 8. Effects of heavy metal concentration (low, medium and high) in food on development time (eclosion from egg to prepupa) of Hermetia illucens larvae., ${ }^{1,2}$

\begin{tabular}{|c|c|c|c|c|c|c|c|c|}
\hline & \multicolumn{2}{|l|}{ Control } & \multicolumn{2}{|l|}{ Low } & \multicolumn{2}{|l|}{ Medium } & \multicolumn{2}{|l|}{ High } \\
\hline & Mean (days) & SE & Mean (days) & SE & Mean (days) & SE & Mean (days) & SE \\
\hline Cadmium & $18.4 a b$ & 0.5 & $18.0 \mathrm{a}$ & 0.5 & $18.8 \mathrm{ab}$ & 0.4 & $19.3 b$ & 0.6 \\
\hline Lead & $18.4 a$ & 0.5 & $18.8 \mathrm{ab}$ & 0.3 & $19.4 b$ & 0.4 & $20.7 c$ & 0.2 \\
\hline Zinc & $18.4 \mathrm{a}$ & 0.5 & $\mathrm{n} / \mathrm{a}$ & - & $18.9 \mathrm{a}$ & 0.5 & $20.1 b$ & 0.6 \\
\hline
\end{tabular}

\footnotetext{
${ }^{1}$ Mean values followed by the same small letter in the same row do not vary significantly $(P>0.05)$.

${ }^{2} \mathrm{SE}=$ standard error; $\mathrm{n} / \mathrm{a}=$ not applicable.
} 

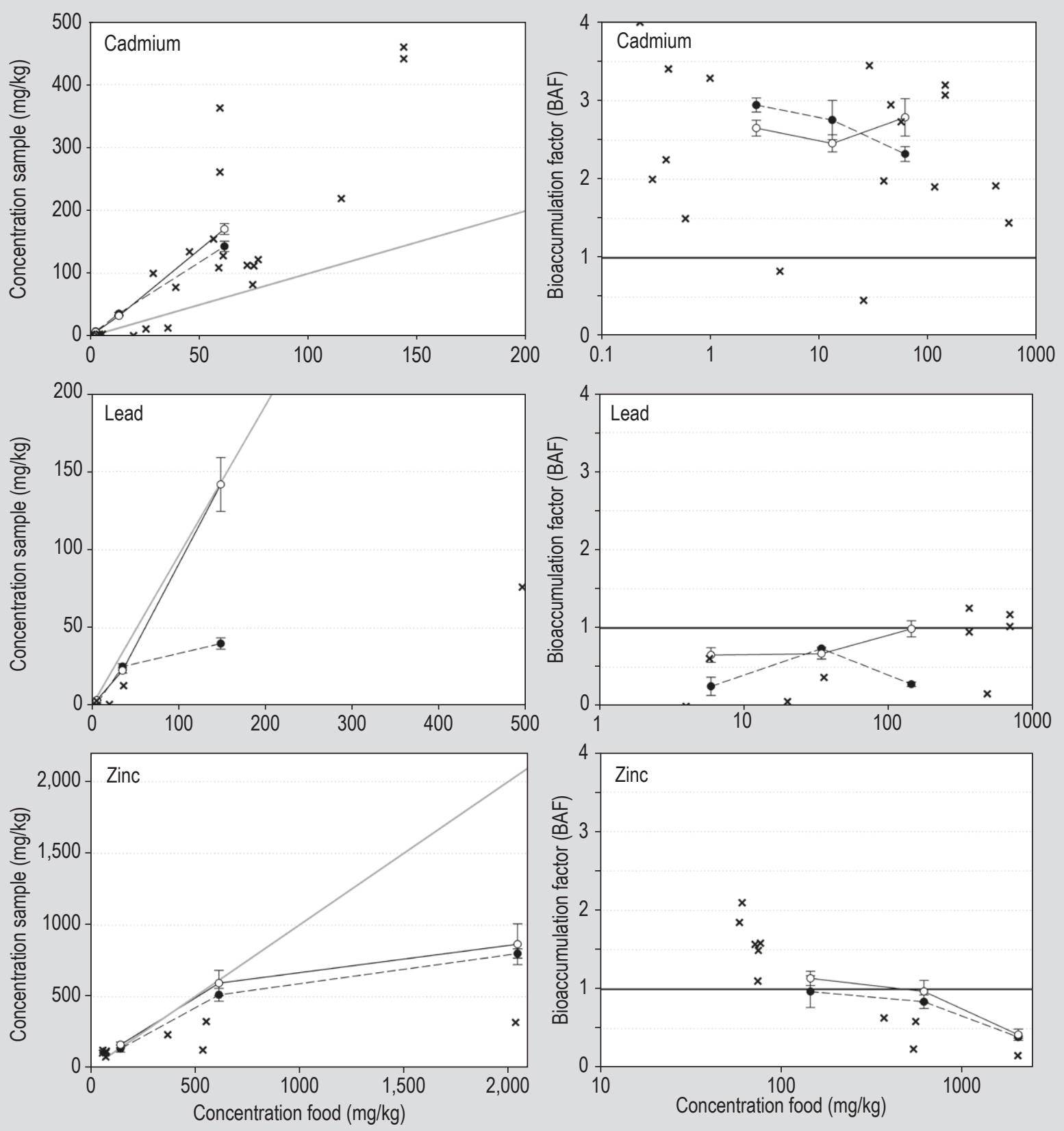

Figure 1. Concentration and bioaccumulation factor (BAF) of heavy metals in black soldier fly larvae $(0)$ and prepupae $(\bullet)$, which were fed with heavy metal spiked food (current study). Crosses show data from literature which originates from similar studies about heavy metal concentrations in various insect larvae (Cd: Kazimirova and Ortel, 2000; Kramarz, 1999; Lindqvist, 1992; Maryanski et al., 2002; Ortel, 1995; Pb: Gintenreiter et al., 1993; Kazimirova and Ortel, 2000; Ortel, 1995; Zn: Kramarz, 1999; Maryanski et al., 2002). 1:1 line shown for reference. Missing BAF values are attributed to undetectable concentrations in control groups.

In contrast to cadmium, the BAF for zinc decreased with increasing zinc concentration in the food, which suggests active regulation of zinc within the body (Table 6). Similarly, larvae of the house fly, fed with zinc-contaminated food (from 61 to $>7,000 \mathrm{mg} / \mathrm{kg}$ ) accumulated zinc only up to a maximum level of $216 \mathrm{mg} / \mathrm{kg}$ (Kramarz, 1999; Maryanski et al., 2002). Even though the mean zinc concentration in the literature data for Musca domestica is lower than that found in prepupae of $H$. illucens of the present study
(484 $\mathrm{mg} / \mathrm{kg}, \mathrm{SE}=97.5$ ), it is possible that the two organisms possess a similar regulation mechanism.

Active regulation of zinc in insects has been described previously (Lindqvist, 1995; Mason et al., 1983). Zinc is an essential, yet potentially toxic element. Therefore, it is not surprising that its intracellular uptake is actively regulated. Especially the metal-responsive-element-binding transcription factor-1 (MTF-1) is a key regulator in higher 
eukaryotic cells. It is responsible for the activation of several genes involved in intracellular zinc sequestration and transport (Laity and Andrews, 2007).

Though larvae and prepupae contained low lead concentrations in the present study, the larval exuviae accumulated lead. Lead tends to be stored in granular, metal-containing structures of the cells before it is transported to and immobilised in the exoskeleton (Hare, 1992). Similar to terrestrial insects, lead is most likely disposed of during moulting (Roberts and Johnson, 1978).

Heavy metal concentration in adults was significantly lower than in prepupae. We assume that this phenomenon occurs mainly because animals defecate before pupation or shortly after adult emergence. Yet Sheppard et al. (1994) reported without supporting data that prepupae had an empty gut when migrating. Conversely, Aoki and Suzuki (1984) describe an over $50 \%$ loss of the larva's cadmium content due to defecation in newly emerged flesh flies within the first two days following emergence. In the present study, prepupae were collected 1-3 days after transformation. We assume that defecation had not occurred during this period, and cadmium was removed during the later prepupal phase, i.e. during pupation, or after emergence. Therefore, toxic substances and pathogens present in the waste may remain in the gut of the harvested prepupae and in this way may be taken up by fishes or poultry fed with the prepupae. Future studies have to determine the period between initiation of the last larval instar (prepupa) and defecation, including the potential loss of feedstuff energy due to such a protraction.

The effective elimination of heavy metals by defecation has been described for larvae of the social paper wasp Polistes dominulus (Hymenoptera: Vespidae) (Urbini et al., 2006). However, even if heavy metals accumulate in the cells lining the alimentary canal, they may be rejected after a short time. For example, Tenebrio molitor (Coleoptera: Tenebrionidae) discards cells of the midgut epithelium after four days (Lindqvist and Block, 1995; Thomas and Gouranto, 1973). Heavy metal accumulated in these cells will therefore be rejected with defecation.

\section{Conclusions}

Our studies reveal that the concentrations of lead and zinc in larvae or prepupae remain below the initial amounts in the food. Furthermore, the three heavy metal elements examined had only minor effects on the development of the black soldier fly even at very high concentrations. Yet, since cadmium accumulated in the prepupae, it could potentially limit the use of prepupae in the production of animal feed. In the case of lead and zinc, concerns about the use of prepupae in animal feed are less critical. The waste treatment technology using black soldier flies may contribute to reducing the burden of an animal protein shortage in the animal feed market and provide new income opportunities for small entrepreneurs in low and middleincome countries.

\section{Acknowledgements}

We wish to express our thanks to Simone Blaser and Mauro Esposito for assisting during the experiments, David Kistler for supporting us in lab analysis and Alejandra Teresita Arroyo for her statistical advice. We appreciate the comments by Janet Hering on an early version of the manuscript, and are grateful to Sylvie Peter for linguistic editing support. The authors would like to acknowledge the financial support by the Velux Foundation, Eawag: the Swiss Federal Institute of Aquatic Science and Technology, the Swiss National Centre of Competence in Research (NCCR North South) and the Swiss Agency for Development and Cooperation (SDC).

\section{References}

Alam, M.G.M., Snow, E.T. and Tanaka, A., 2003. Arsenic and heavy metal contamination of vegetables grown in Samta village, Bangladesh. Science of the Total Environment 308: 83-96.

Aoki, Y. and Suzuki, K.T., 1984. Excretion of cadmium and change in the relative ratio of iso-cadmium-binding proteins during metamorphosis of fleshfly (Sarcophaga peregrina). Comparative Biochemistry and Physiology, Part C: Toxicology \& Pharmacology 78: 315-317.

Booram, C.V., Newton, G.L., Hale, O.M. and Barker, R.W., 1977. Manure as a substrate for protein production via Hermetia illucens larvae. In: Proceedings of the Cornell agricultural Waste Management Conference, Cornell University, Ithaca, NY, USA, pp. 599-604.

Braeckman, B., Smagghe, G., Brutsaert, N., Cornelis, R. and Raes, H., 1999. Cadmium uptake and defense mechanism in insect cells. Environmental Research 80: 231-243.

Council for International Organizations of Medical Sciences (CIOMS), 1985. International guiding principles for biomedical research involving animals. CIOMS, Geneva, Switzerland. Available at: http://tinyurl.com/pj4p8tg.

Diener, S., Studt Solano, N.M., Roa Gutiérrez, F., Zurbrugg, C. and Tockner, K., 2011. Biological treatment of municipal organic waste using black soldier fly larvae. Waste and Biomass Valorization 2: 357-363.

Diener, S., Zurbrügg, C. and Tockner, K., 2009. Conversion of organic material by black soldier fly larvae - establishing optimal feeding rates. Waste Management \& Research 27: 603-610.

Eklind, Y., Beck-Friis, B., Bengtsson, S., Ejlertsson, J., Kirchmann, H., Mathisen, B., Nordkvist, E., Sonesson, U., Svensson, B.H. and Torstensson, L., 1997. Chemical characterization of source-separated organic household wastes. Swedish Journal of Agricultural Research 27: $167-178$. 
European Commission (EC), 1991. Council Regulation (EC) no. 2092/91 on organic production of agricultural products and indications referring thereto on agricultural products and foodstuffs. Official Journal of the European Union L198: 1.

European Commission (EC), 2001. Commission Regulation (EC) no. 1881/2006 of 19 December 2006 on setting maximum levels for certain contaminants in foodstuffs. Official Journal of the European Union L364: 5-24.

European Commission (EC), 2002. Directive 2002/32/EC of the European Parliament and of the Council of 7 May 2002 on undesirable substances in animal feed. Official Journal of the European Union L140: 10.

Fluitman, F., 2000. Training and work in the informal sector of developing countries: issues and good practice. International Labour Organization, Turin, Italy. Available at: http://tinyurl.com/qhneqz2.

Gintenreiter, S., Ortel, J. and Nopp, H.J., 1993. Bioaccumulation of cadmium, lead, copper, and zinc in successive developmental stages of Lymantria dispar L. (Lymantriidae, Lepid) - a life-cycle study. Archives of Environmental Contamination and Toxicology 25: 55-61.

Görür, G., 2006. Developmental instability in cabbage aphid (Brevicoryne brassicae) populations exposed to heavy metal accumulated host plants. Ecological Indicators 6: 743-748.

Government of India, 1954. The prevention of food adulteration act (Act 37 of 1954). Government of India, Delhi, India.

Hare, L., 1992. Aquatic insects and trace metals: bioavailability, bioaccumulation, and toxicity. Critical Reviews in Toxicology 22: 327-369.

Hoornweg, D., Thomas, L. and Otten, L., 1999. Composting and its applicability in developing countries. The World Bank, Washington, DC, USA.

Kazimirova, M. and Ortel, J., 2000. Metal accumulation by Ceratitis capitata (Diptera) and transfer to the parasitic wasp Coptera occidentalis (Hymenoptera). Environmental Toxicology and Chemistry 19: 1822-1829.

Kramarz, P., 1999. Dynamics of accumulation and decontamination of cadmium and zinc in carnivorous invertebrates. 1. The ground beetle, Poecilus cupreus L. Bulletin of Environmental Contamination and Toxicology 63: 531-537.

Lagisz, M. and Laskowski, R., 2008. Evidence for between-generation effects in carabids exposed to heavy metals pollution. Ecotoxicology 17: 59-66

Laity, J.H. and Andrews, G.K., 2007. Understanding the mechanisms of zinc-sensing by metal-response element binding transcription factor-1 (MTF-1). Archives of Biochemistry and Biophysics 463: 201-210.

Leary, R.F. and Allendorf, F.W., 1989. Fluctuating asymmetry as an indicator of stress - implications for conservation biology. Trends in Ecology \& Evolution 4: 214-217.

Lindqvist, L., 1992. Accumulation of cadmium, copper, and zinc in 5 species of phytophagous insects. Environmental Entomology 21: 160-163.

Lindqvist, L., 1995. Influence of metal concentrations in food on metal uptake and accumulation in sawfly larvae. Archives of Environmental Contamination and Toxicology 28: 310-313.
Lindqvist, L. and Block, M., 1995. Excretion of cadmium during molting and metamorphosis in Tenebrio molitor (Coleoptera, Tenebrionidae). Comparative Biochemistry and Physiology, Part C: Toxicology \& Pharmacology 111: 325-328.

Liu, X.D., Zhai, B.P., Zhang, X.X. and Zong, J.M., 2005. Impact of transgenic cotton plants on a non-target pest, Aphis gossypii Glover. Ecological Entomology 30: 307-315.

Marshall, F., 2003. Enhancing food chain integrity: quality assurance mechanisms for air pollution impacts on fruit and vegetable systems. Project record R7530. Imperial College London, London, UK.

Marshall, F., Agarwal, R., Te Lintelo, D., Bhupal, D.S., Singh, R.P.B., Mukherjee, N., Sen, C., Poole, N., Agrawal, M. and Singh, S.D., 2003. Heavy metal contamination of vegetables in Delhi. Imperial College London, London, UK.

Maryanski, M., Kramarz, P., Laskowski, R. and Niklinska, M., 2002. Decreased energetic reserves, morphological changes and accumulation of metals in carabid beetles (Poecilus cupreus L.) exposed to zinc- or cadmium-contaminated food. Ecotoxicology 11: 127-139.

Mason, W.H., Wit, L.C. and Blackmore, M.S., 1983. Bioelimination of Zn-65 in Popilius disjunctus after a dietary zinc supplement. Journal of the Georgia Entomological Society 18: 246-251.

Moore, M., Gould, P. and Keary, B.S., 2003. Global urbanization and impact on health. International Journal of Hygiene and Environmental Health 206: 269-278.

Moroń, D., Szentgyörgyi, H., Skórka, P., Potts, S.G. and Woyciechowski, M., 2014. Survival, reproduction and population growth of the bee pollinator, Osmia rufa (Hymenoptera: Megachilidae), along gradients of heavy metal pollution. Insect Conservation and Diversity 7: 113-121.

Myers, H.M., Tomberlin, J.K., Lambert, B.D. and Kattes, D., 2008. Development of black soldier fly (Diptera: Stratiomyidae) larvae fed dairy manure. Environmental Entomology 37: 11-15.

Ortel, J., 1995. Accumulation of $\mathrm{Cd}$ and $\mathrm{Pb}$ in successive stages of Galleria mellonella and metal transfer to the pupal parasitoid Pimpla turionellae. Entomologia Experimentalis et Applicata 77: 89-97.

Riddick, E.W., 2014. Insect protein as a partial replacement for fishmeal in the diets of juvenile fish and crustaceans. In: Morales-Ramos, J., Guadalupe Rojas, M. and Shapiro-Ilan, D. (eds.) Mass production of beneficial organisms. Academic Press, San Diego, CA, USA, pp. 565-582.

Roberts, R.D. and Johnson, M.S., 1978. Dispersal of heavy metals from abandoned mine workings and their transference through terrestrial food chains. Environmental Pollution 16: 293-310.

Rytz, I., 2001. Assessment of a decentralised composting scheme in Dhaka, Bangladesh - technical, operational, organisational and financial aspects. Eawag/Sandec and Waste Concern, Zurich, Switzerland.

Sharma, R.K., Agrawal, M. and Marshall, F., 2007. Heavy metal contamination of soil and vegetables in suburban areas of Varanasi, India. Ecotoxicology and Environmental Safety 66: 258-266.

Sheppard, D.C., Newton, G.L., Thompson, S.A. and Savage, S., 1994. A value-added manure management-system using the black soldier fly. Bioresource Technology 50: 275-279. 
St-Hilaire, S., Sheppard, D.C., Tomberlin, J.K., Irving, S., Newton, G.L., McGuire, M.A., Mosley, E.E., Hardy, R.W. and Sealey, W., 2007. Fly prepupae as a feedstuff for rainbow trout, Oncorhynchus mykiss. Journal of the World Aquaculture Society 38: 59-67.

Thomas, D. and Gouranto, J., 1973. Durée de formation des cristaux protéiques intranucléaires de l'intestine moyen de Tenebrio molitor. Journal of Insect Physiology 19: 515-522.

Tomberlin, J.K. and Sheppard, D.C., 2002. Factors influencing mating and oviposition of black soldier flies (Diptera: Stratiomyidae) in a colony. Journal of Entomological Science 37: 345-352.
Urbini, A., Sparvoli, E. and Turillazzi, S., 2006. Social paper wasps as bioindicators: a preliminary research with Polistes dominulus (Hymenoptera Vespidae) as a trace metal accumulator. Chemosphere 64: 697-703.

Walker, C.H., 1990. Kinetic-models to predict bioaccumulation of pollutants. Functional Ecology 4: 295-301.

Zurbrügg, C., Rothenberger, S., Vögeli, Y. and Diener, S., 2007. Organic solid waste management in a framework of millennium development goals and clean development mechanism. In: Diaz, L.F., Eggerth, L.L. and Savage, G.M. (eds.) Management of solid wastes in developing countries. CISA, Padova, Italy, 430 pp. 